\title{
Paweł Biliński
}

\author{
Uniwersytet Gdański
}

\section{Dokument z pulpitu. \\ O kulisach powstania, \\ narracji i kontekstach}

\section{Transformers: The Premake Kevina B. Lee}

Nazwisko Kevina B. Lee należy do najczęściej przywoływanych w zestawieniach najważniejszych wideoeseistów. Amerykanin przez ostatnią dekadę dał się poznać nie tylko jako twórca oryginalnie zmontowanych audiowizualnych utworów traktujących o kinie współczesnym, ale też osoba, która może pochwalić się dobrą znajomością komputerowego oprogramowania (także tego podstawowego, w postaci środowiska Microsoft Office), sprawnie przezeń wykorzystywanego do komponowania krytycznych „tekstów” o kinie. Wideoeseje jego autorstwa, regularnie umieszczane na platformach YouTube i Vimeo, doceniano za analityczną staranność, niebanalne spostrzeżenia, wreszcie - za przekonujące zestawianie scen z interpretowanych filmów. I choć liczba obserwatorów konta Lee na Twitterze nie robi wrażenia, oscylując od kilku lat na poziomie 7 tysięcy zainteresowanych, trzeba pamiętać, że mowa o entuzjastach ambitnej wideoeseistyki, nie zaś odbiorcach zadowalających się oglądaniem internetowych filmów w rodzaju „Top 10”, w których wyspecjalizowały się niektóre kanały na YouTubie (choćby WatchMojo.com). Pozycja Lee w świecie tego rodzaju krytycznej praktyki od pewnego czasu jest ustabilizowana, co potwierdzają wygłaszane przez niego na światowych uniwersytetach wykłady gościnne i uczestnictwo w istotniejszych panelach poświęconych realizacji podobnych utworów. 
Metoda Lee ma swoje źródła w eseistyce filmowej Chrisa Markera, Jean-Luca Godarda czy Haruna Farockiego ${ }^{1}$. Przywołani twórcy zacierali granice między kinem fikcjonalnym a dokumentalizmem - w obrębie realizowanych dzieł zestawiali oni fragmenty różnych filmów oraz wzbogacali audiowizualny przekaz o nagraną przez siebie narrację z offu, niejednokrotnie przy tym koncentrując się na samym medium ${ }^{2}$. Za swoisty pomost pomiędzy twórczością wyżej wymienionych a pracami Lee można uznać wielokrotnie wspominane przez tego ostatniego kinofilskie realizacje amerykańskiego dokumentalisty Marka Rappaporta ${ }^{3}$. Ich podobieństwo do współczesnej odmiany wideoesejów ${ }^{4}$ wiąże się z faktem, że Rappaport korzystał niemal wyłącznie z fragmentów innych filmów, umieszczając je w zaskakujących kontekstach ${ }^{5}$ i dodając komentarz z offu, w którym koncentruje się nade wszystko na narracji, estetyce i teorii, co ma wiele wspólnego z utworami publikowanymi w sieci, a określanymi już mianem wideoesejów. Co ciekawe, Rappaport z czasem zaczął posługiwać się nowoczesną aparaturą komputerową i umieszczać swoje prace w internecie - „naturalnym środowisku” wideoeseistyki, która wręcz mogłaby nie zaistnieć, gdyby nie platformy YouTube i Vimeo. Przeszło dekadę temu pisała o tym Iwona Kurz:

Można by sądzić, że serwis YouTube przyciąga wielu miłośników filmu; liczne spośród zamieszczonych w nim wypowiedzi mają charakter cytatów i odniesień do istniejących dzieł filmowych lub rozmaitych montaży, przeróbek, odegrań i powtórzeń znanych scen i sekwencji. Jest zatem ten serwis polem, celem (i efektem) rozmaitych praktyk nadawczo-odbiorczych, w pewnym sensie także kolekcjonerskich, związanych z filmem (Kurz, 2010, s. 417).

Otwarty internetowy dostęp do filmów Lee, podobnie jak do dzieł innych wideoeseistów, wydaje się jednym z czynników wyróżniających tę formę wypowiedzi. Realizacja wideoesejów jest produktem kultury opartej na aktywnym współuczestnictwie w rozmyślaniach nad sztuką filmową i dzieleniu się swoimi

1 Eseistyka filmowa „zainicjowała pytanie o możliwość przeprowadzenia za pomocą środków audiowizualnych wywodu demonstracyjnie niefikcjonalnego i niesystemowego, podszywającego się pod różnego rodzaju wypowiedzi i style" (Świętochowska, 2018, s. 7). Pod względem genologicznym wideoesej odczytywany jest jako rozwinięcie formuły wypracowanej przez wspomnianych reżyserów.

2 Więcej informacji na temat narracji i definiowania eseju filmowego zob. Zając, 2010, s. 75-96.

3 Filmom Rappaporta Lee poświęcił osobny, nostalgiczny wideoesej zatytułowany Breaking through the Screen. Video Essays of Mark Rappaport, https://vimeo.com/196762561 (dostęp: 20.08.2020).

4 Warto odnotować, że nie zawsze filmy Rappaporta są w ten sposób interpretowane. Phillip Lopate w swym szkicu monograficznym wspomina co prawda o „metodzie kolażu” stosowanej przez artystę, ale nie odnosi się do jego filmów jako wideoesejów. Zob. Lopate, 2020, s. 30-33.

5 Doskonałym przykładem jest tu film Rock Hudson's Home Movies (1992), którego narrację kształtuje mozaika cytatów z filmów ze słynnym amerykańskim aktorem, odczytywanych przez pryzmat skrywanej przez Hudsona orientacji psychoseksualnej. 
spostrzeżeniami. YouTube (oraz Vimeo) ,jest kluczową witryną, na której możemy oglądać aktywne dyskursy kultury partycypacji i pojawienie się twórczego, zyskującego na znaczeniu konsumenta" (Burgess, Green, 2014, s. 386). Zwracam szczególną uwagę na wspomniane serwisy nie tylko ze względu na ich znaczenie dla współczesnej wideoeseistyki (a tym samym twórczości Lee). YouTube - oraz związana z nim partycypacja - bywa bowiem jednym z tematów podobnych filmów, traktujących nie tylko o kinie, ale też o sposobach i możliwościach jego reinterpretowania czy remiksowania w domowym (lub innym) zaciszu. Ta samozwrotność sprawiła, że można też wskazać wideoeseje, które w pewien sposób wpisują się w obszar audience studies. Jeden z najważniejszych tego rodzaju utworów zmontował (zrealizował? wyreżyserował?) Kevin B. Lee.

\section{Droga do premake'u}

Pośród intelektualnie zdyscyplinowanych wideoesejów Lee raczej trudno znaleźć dogłębne analizy blockbusterów z ostatnich lat, choć dzięki ewentualnemu zmontowaniu utworów na ich podstawie z pewnością łatwiej byłoby zgromadzić większą grupę obserwatorów Alsolikelife.com - serwisu prowadzonego przez Amerykanina. Zamiast skupiać się na kinie głównego nurtu, Lee:

„(...) woli rozstrzygać tajemnice z niemieckiego Dziwnego matego kota (2013, R. Zürcher), „pisać” audiowizualny list do kambodżańskiego reżysera Brakujacego zdjęcia (2013, R. Panh), badać zakamarki No Home Movie (2015, Ch. Akerman), oddawać hołd dokumentowi W obręczy marzeń (1994, S. James), prezentować różne interpretacje Lewiatana (2012, L. Castaing-Taylor, V. Paravel). czy odkrywać po latach zapomniany film polskiego reżysera (Ceremonie mitości [1987, W. Borowczyk])" (Biliński, 2016, s. 16).

Bogate spektrum odniesień potwierdzają takie wideoeseje, jak The Spielberg Face (2011), w którym Lee analizował filmy reżysera Szczęk (1975) pod kątem wielokrotnie pojawiających się w nich zbliżeń twarzy protagonistów, What Is Lynchian? (2016), rozwiający refleksję nad lynchowską estetyką czy Terrence Malick: The Art of Voiceover (2014) - praca koncentrująca się na znaczeniu głosu z offu, tak chętnie stosowanego przez ekscentrycznego autora Drzewa życia (2011). Regularne publikowanie różnorodnych wideoesejów - tworzonych nieprzerwanie od 2007 roku, kiedy to Lee doszedł do wniosku, że samo pisanie o filmach nie wystarcza do ich zadowalającego zgłębienia (Lee, 2009) - doprowadziło do sytuacji, którą Amerykanin po latach wspominał jako trudną do zniesienia ze względu na konieczność spędzania przed komputerem co najmniej kilkunastu godzin dziennie (Lee, 2020). Pragnienie nakręcenia czegoś kamerą poza domem stało się jednym 
z katalizatorów wiodących ostatecznie do realizacji dwudziestopięciominutowego Transformers: The Premake z 2014 roku - nagradzanego wideoeseju, który jako jeden z nielicznych może się pochwalić wymienieniem w bazie IMDB, największym światowym serwisie filmowym, gdzie otagowany jest hasłami: „krótkometrażowy”, „dokument”, „sci-fi”. O ile ostatnie określenie jest mylące - Transformers: The Premake jedynie odnosi się do filmu science fiction (jeśliby posłużyć się uproszczonym rozumieniem tej kategorii $-\mathrm{z}$ nauką seria Transformers ma bowiem niewiele wspólnego), nie wpisując się samodzielnie w ramy gatunku - o tyle z resztą wypada się zgodzić: wspomniany wideoesej można uznać za stosunkowo niedługi utwór niefikcjonalny. W przeciwieństwie jednak do swoich wcześniejszych wideoesejów w tym wypadku Lee wykorzystał przede wszystkim bardzo różne materiały audiowizualne znalezione $\mathrm{w}$ internecie oraz, najprawdopodobniej po raz pierwszy, ujęcia nakręcone samodzielnie. Najbardziej jednak zastanawiający jest sam temat wideoeseju. Transformers: The Premake odnosi się do Transformers: Wieku zagtady (2014, reż. M. Bay), a więc filmu, który w trakcie montowania wspomnianego wideoeseju był jeszcze w fazie produkcji i postprodukcji, a zarazem filmu, który pod względem estetyczno-narracyjnym niekoniecznie powinien był zainteresować Lee na tle jego dotychczasowych wyborów.

\section{Reportaż(e) z planu}

Wbrew swojemu tytułowi Transformers: The Premake nie traktuje o robotach ratujących świat. Fabuła poprzednich części widowiskowej sagi (Wiek zagtady to czwarta odsłona serii, którą zapoczątkowano w 2007 roku) również nie jest przedmiotem zainteresowania Lee. Na pierwszym planie wideoeseju autor sytuuje proces produkcji, czyli aspekt filmu, który dotychczas mniej go interesował jako twórcę i krytyka, relatywnie rzadko uwzględniany także przez innych wideoeseistów. Jako paratekst typu making-of utwór Lee wyróżnia się na tle podobnych dokumentów - nie jest fanowską ciekawostką, nie prezentuje szczegółowo kulis realizacji filmu, nie jest też rozbudowaną i krytyczną analizą, rekonstruującą wieloetapowy przebieg powstawania Wieku zagtady. Nie ma tu "gadających głów" (a nawet jeśli się pojawiają, to jedynie w formie cytatów z telewizyjnego programu), zakulisowych wywiadów z twórcami Transformers, wypowiedzi fanów, pokazów budowy dekoracji czy prac nad udoskonaleniem ujęć CGI. Autor nie rości sobie również pretensji do bycia ekspertem w zakresie kręcenia tego rodzaju filmów. Na potrzeby przygotowania Premake’u nie przeprowadził też wywiadu z samym reżyserem - nawet jeśli by to zrobił, to tego rodzaju rozmowa najpewniej nie zostałaby zresztą użyta. Trudno sobie wyobrazić, by Lee reprezen-

\footnotetext{
${ }^{6}$ Więcej o strukturze dokumentów making-of zob. Kożuchowski, 2019, s. 70-74.
} 
tował studio Paramount Pictures (odpowiedzialne za produkcję Wieku zagtady); Premake nie nadaje się bowiem do promocji wysokobudżetowego blockbustera i sami producenci z pewnością nie pozwoliliby sobie na umieszczenie tego utworu na płytach DVD lub blu-ray z wydaniem Wieku zagtady ${ }^{7}$. Nie taki był też, rzecz jasna, cel twórcy wideoeseju.

Pierwszą cechą wyróżniającą Transformers: The Premake na tle oficjalnych materiałów z planu jest data premiery. Lee jeszcze na etapie montowania postanowił, że wideoesej winien być ukończony (i umieszczony na platformie w sieci) przed pierwszymi oficjalnymi seansami Wieku zagtady (Lee, 2020), dzięki czemu zostałoby podkreślone, w jakim stopniu nad tekstem przeważa kontekst realizacji. Nawiasem mówiąc, cel udało się zrealizować, gdyż Premake na Vimeo opublikowano 5 maja 2014 r., zaś premiera filmu studia Paramount miała miejsce w Hongkongu nieco ponad miesiąc później, 19 czerwca. Wspomniana kwestia ma też związek z tytułem wideoeseju - niemający polskiego odpowiednika neologizm nie bez przyczyny przypomina słowo remake. Swój pomysł Lee tłumaczył w jednym z wywiadów, w którym zaznaczał, że chciał iść pod prąd trendom kręcenia wariacji tego, co już było (czyli remake’ów) i zrobić własną wersję Wieku zagtady, zanim będzie go można zobaczyć w kinach (Steffen, 2015).

Premake z fabułą dzieła Baya, jak wspomniano, niewiele ma wspólnego. W centrum zainteresowania twórcy wideoeseju znajduje się przede wszystkim proces realizacji blockbustera, z którym zapoznajemy się, oglądając fragmenty amatorskich nagrań z miejsca kręcenia filmu Paramount Pictures. Cytatową kompozycję Premake’u buduje kolaż youtube'owych filmików, które przez kilka miesięcy Lee skrupulatnie kolekcjonował (jak sam twierdzi - zebrał ich 355 [Lee, 2020]), przy okazji odnotowując, gdzie akurat odbywały się zdjęcia do kolejnych sekwencji. Wspomnianych nagrań Lee szukał za pomocą prostych haseł typu: „Transformers 4 Detroit”, „Transformers 4 Chicago”, „Transformers 4 behind the scenes” itp., wpisywanych do wyszukiwarki YouTube’a (Lee, 2020). Na zestaw materiałów składają się nagrania przede wszystkim z Detroit (115 utworów) i Chicago (148 filmów), ale Lee dotarł też do relacji z innych miast - jednego filmu z Utah i Waszyngtonu, czterech nakręconych w Michigan, ośmiu zrealizowanych w stanie Teksas. Ponadto w Premake'u zacytowano nagrania z Chin oraz Hongkongu - gdzie również miały miejsce zdjęcia do Wieku zagtady, i gdzie amatorzy przygotowali 52 nieoficjalne filmy. Lee cytuje także materiały analizujące zwiastuny, jak również takie, w których spekuluje się na temat ewentualnych bohaterów czwartej odsłony

\footnotetext{
Nawiasem mówiąc, łączny czas trwania materiałów dodatkowych umieszczonych na dysku bluray z filmem Transformers: Wiek zagłady przekracza czas projekcji przeszło dwuipółgodzinnego metrażu (Liebman, 2014), co tylko podkreśla, jak duży nacisk kładą pracownicy Paramountu na przygotowanie paratekstów przybliżających proces realizacji wyprodukowanego przez nich filmu.
} 
Transformers. Krytyk sięga nie tylko po utwory audiowizualne - w jego wideoeseju znalazły się ujęcia prezentujące strony internetowych serwisów, fora o cyklu Transformers i fragmenty tekstów znalezionych w sieci.

Lee, jak zostało już powiedziane, nad oficjalne materiały typu making-of przedkłada amatorskie i półamatorskie utwory, kręcone zazwyczaj za pomocą telefonu komórkowego lub smartfona. Warto dodać, że umieszczenie tego rodzaju filmów na platformie YouTube nie musiało wzbudzać sprzeciwu przedstawicieli Paramount. Wprost przeciwnie - studio często nie zgłaszało administratorom serwisu naruszenia praw, ale wręcz wykorzystywało obecność i zaangażowanie fanów uniwersum robotów w szerzenie informacji o powstającym właśnie Wieku zagłady. To o tyle znamienne, że nie każde wideo mogło znaleźć się w szerszym dostępie - co także Premake wypunktowuje w scenie ukazującej wymianę wiadomości między Lee a jednym z użytkowników, któremu ze względu na naruszenie praw autorskich skasowano nakręcony przezeń film z miejsca realizacji blockbustera. Zdaniem jednego z krytyków fragmenty te dowodzą, że wideoesej Lee ma ambicję stanowić komentarz odnoszący się do tzw. crowdsourced movie promotion (Skinner, 2014), czyli działań odbiorców, którzy na własną rękę reklamują dany utwór. Kazus Wieku zagłady dowodzi, że wolność w ustalaniu toru tego typu promocji jest fikcją studio może momentalnie zablokować niepożądany przez siebie przekaz, zaburzający dokładny harmonogram reklamowania produkcji. Koresponduje to poniekąd z tezą Johna Thorntona Caldwella, autora książki Production Culture: Industrial Reflexivity and Critical Practice in Film and Television, według którego naczelną fantazją dzisiejszego Hollywood jest, by „uzyskać produkt w najniższej możliwej cenie lub za darmo i sprawić, by wszyscy pracowali dla ciebie bez wynagrodzenia" (Adamczak, 2015, s. 26). Doskonale to obrazuje jedna z ostatnich scen Premake'u, w której widzimy kilkoro stojących przy płocie gapiów, rejestrujących za pomocą telefonów komórkowych członków ekipy filmowej Wieku zagtady, akurat grających rekreacyjnie w piłkę. Wśród nich jest Mark Wahlberg, gwiazdor czwartej części Transformers, dostrzeżony w pewnym momencie przez rozentuzjazmowaną fankę. Żadnej z osób nie będzie dane przekroczyć płotu. O braku możliwości przejścia tej granicy - rozumianej również metaforycznie: jako przepaści dzielącej fana i reprezentanta pionu produkcji - także traktuje wideoesej Lee.

Inne znaczące w tym kontekście ujęcie - jedno z niewielu zarejestrowanych przez Lee na potrzeby swojego dzieła - można znaleźć w scenie nakręconej w kawiarni, gdzie kilka osób za pomocą telefonów filmuje przez okno nadjeżdżające sportowe i luksusowe samochody, zapewne przygotowywane do występu w superprodukcji Baya. Stoi tam również niewidoczny w kadrze Lee skupiony na ludziach zafascynowanych fermentem produkcyjnym - co sygnalizuje 
kompozycja ujęcia, w którym auta są na drugim planie. „Zdałem sobie sprawę, że nie jestem sam - że takich jak ja jest mnóstwo" - wspominał później autor (Lee, 2020). Premake to więc na swój sposób utwór dokonujący zaklasyfikowania współczesnej popkultury, bazującej na stale zwiększającej się roli fanów i odbiorców (w procesie odbioru i współuczestnictwa w szeroko pojętym spektaklu) względem poprzednich lat. Fakt ten podkreśla także złożona narracja dzieła, za sprawą której do wideoeseju Lee odnoszono się jako jednego z prekursorskich desktop documentaries.

\section{Dokument zarejestrowany na pulpicie}

Desktop documentary to kontynuujący tradycje eseju filmowego utwór niefikcjonalny, realizowany w całości w cyfrowej przestrzeni przy wykorzystaniu odpowiedniego oprogramowania. Pozwala ono na montaż i manipulację już istniejącymi materiałami, najczęściej zaczerpniętymi z internetu (Bešlagić, 2019, s. 52). To także - w jeszcze większym stopniu, aniżeli powstałe dotychczas eseje filmowe - gatunek per se autotematyczny. Desktop documentary nie tylko realizowany jest na pulpicie komputera (co samo w sobie nie stanowi przecież innowacji), ale również bezpośrednio prezentuje zawartość pulpitu. Dzięki tej optyce eksplicytnie zostają opisane stosowane przez twórcę narzędzia i metoda, co pomaga nie tylko w zgłębieniu danego tematu, na którym utwór się koncentruje, ale również w uwypukleniu autorskiej perspektywy i sposobów charakteryzowania danej problematyki.

Taką narrację Premake’u zapowiadają już pierwsze sekundy dzieła. Ujęcie otwierające wideoesej prezentuje pulpit MacBooka Pro - tytuł filmu zostaje zapisany w edytorze tekstów (w momencie wklepywania kolejnych liter słyszymy charakterystyczne dźwięki klawiatury), zaś po zminimalizowaniu okna widzimy desktop z trzema folderami: dyskiem twardym nazwanym "Adorno" ${ }^{\text {, dyskiem }}$ zewnętrznym określonym jako „Farocki”9 oraz folderem „Transformers”. Pulpit ozdabia zaś tapeta ze stopklatką z animowanego serialu przedstawiającą głowę Grimlocka - jednego z Dinobotów (robotów przemieniających się w maszyny dinozauropodobne), który pojawia się również w Wieku zagłady. Ów ekran będziemy oglądać do końca projekcji, a niewidoczny, anonimowy użytkownik, a zarazem

8 Eksplicytne odwołanie do Theodora Adorno nie jest bezzasadne, jako że Lee-jak sam mówi-inspiruje się myślą filozofów z tzw. szkoły frankfurckiej, zwłaszcza Waltera Benjamina i wspomnianego autora studium Esej jako forma (Lee, 2020).

9 Prace i myśl Farockiego były Kevinowi Lee, podobnie jak wielu innym twórcom filmowych esejów, bliskie od dawna. Amerykanin zrealizował serię wideoesejów dla Harun Farocki Institut w Berlinie, instytucji powołanej w 2015 roku przez Goethe-Institut, gdzie był pierwszym rezydującym artystą. Zob. https://www.alsolikelife.com/learning-farocki (dostęp: 20.08.2020). 
narrator, w czasie rzeczywistym będzie otwierać pliki, włączać przeglądarkę, odpalać filmy z YouTube’a (lub odtwarzać te zapisane na dysku), wyróżniać fragmenty tekstów z internetu, pisać maile, a także manipulować dźwiękiem w jednym z filmów za pomocą programu służącego do obróbki wideo. I choć Lee zaznacza, do ilu amatorskich nagrań dotarł, to nie jest w stanie przywołać wszystkiego w swoim wideoeseju. Premake ten nadmiar różnorodnych materiałów uwypukla - na ekranie toczy się swoista walka otwieranych okienek, potwierdzających bogactwo źródeł z informacjami o procesie produkcji, swoisty „,choreograficzny wyczyn przypominający grę cieni lub długie nieprzerwane cięciem ujęcia” (Boone, 2014), jakie znamy z historii kina. Premake dość szybko zaczyna jawić się odbiorcy jako panoptikum pełne audiowizualnych i tekstowych ciekawostek; niekończący się zbiór, z którego wszystkimi komponentami niepodobna się zapoznać.

Analizę przebiegu prac nad filmem Lee zaczyna od pokazania fragmentu zwiastuna, do którego odnośnik w serwisie YouTube pojawia się jako jeden z pierwszych po wpisaniu do wyszukiwarki hasła: „Transformers 4”. Znamienne, że „kamera” koncentruje się na trailerze ${ }^{10}$ ledwie chwilę - po kilku sekundach, jak gdyby znudzona estetyką kolejnego blockbustera, kieruje swoją uwagę na lewą stronę ekranu i „przegląda” pozostałe wyniki wyszukiwania. Kursor myszy wybiera kolejny film do odtworzenia - amatorskie making-of zatytułowane Transformers 4 filming in Chicago - Autobots on Columbus Drive ${ }^{11}$ (ukazujące, zgodnie z tytułem, przejeżdżające przez miasto samochody przygotowywane do wykorzystania w filmie), które z kolei prowadzi do kolejnego podobnego utworu itd. Dość szybko okazuje się, że fabuła nadchodzącego blockbustera nie ma większego znaczenia, bo o wiele istotniejsze od samego filmu jest wszystko to,

10 Skądinąd warto zaznaczyć, że w tym z pozoru nieznaczącym momencie można upatrywać ironii - na ekranie zostaje bowiem wyświetlony kilkusekundowy fragment ze zwiastuna pokazanego w trakcie meczu Super Bowl. Teaser trwa łącznie 33 sekundy, a Lee nie decyduje się na zacy towanie go w całości. Pomijając kwestie praw autorskich, odnotujmy, że wyszukiwarka pokazuje znacznie bardziej złożone zwiastuny, ale narrator i tak dobiera jeden z krótszych; i to tylko po to, by zapożyczyć z niego kilka efektownych ujęć robotów, eksplozji i Marka Wahlberga mówiącego do swoich kompanów, by trzymali się blisko niego („Everybody stick behind me!”). Tyle w zupełności wystarczy, zdaje się twierdzić twórca, by odbiorca wiedział, z jakiego rodzaju filmem mamy do czynienia. Szybka zmiana wektora zainteresowania, zademonstrowana poprzez ukazanie kursora myszy klikającego w kolejne dostępne materiały wideo, wydaje się odautorskim komentarzem dotyczącym samego filmu i jego estetyki - kwestii, która Lee nie zajmowała, i to niezależnie od faktu, że Wiek zagłady wówczas był jeszcze w fazie produkcji.

11 Wciąż można go znaleźć w sieci. Zob. https://www.youtube.com/watch?v=psJnTWok62A (dostęp: 15.09.2020). Zacytowany w Premake’u film na portalu YouTube umieścił Ryan Yzquierdo, założyciel serwisu Seibertron.com - platformy fanowskiej poświęconej serii Transformers. Wideoesej informuje nas także o niemałej liczbie wyświetleń nagrania Yzquierdo w 2013 roku (1,002,201 odsłon); licznik obecnie wskazuje nieco ponad 2,331,000 odtworzeń. Trudno więc dziwić się władzom Paramountu, że zdecydowały się wzmocnić siłę promocji Wieku zagtady również o umożliwienie fanom rejestracji i upowszechniania o rodzaju filmów. 
co dzieje się wokół niego. Tym bardziej, że dzieje się bardzo wiele - kolejne miasta zamieniane są w swoiste place boju, na których dochodzi do autentycznych wybuchów, wyrzucania aut w powietrze, pokazów imponujących samochodów, latających nisko helikopterów filmowanych przez potężną aparaturę. Doskonale widać, na co został przeznaczony opiewający na kwotę przeszło 200 milionów dolarów budżet Wieku zagtady. Jeszcze ważniejsze jest jednak to, że blisko planów zdjęciowych znajdują się fani oraz przypadkowi przechodnie, którzy, decydując się na rejestrację telefonami hollywoodzkiego przepychu, sami stają się częścią złożonej machiny produkcyjno-reklamowej - $\mathrm{i}$ to ich audiowizualne minireportaże z planu, w większości nakręcone, jak zapewne można sądzić, na własny użytek, posłużyły Lee do zbudowania narracji wideoeseju o procesie powstawania czwartej części Transformers.

Remiksowy sposób opowiadania w Premake’u bazuje nie tylko na zestawianiu kolejnych fragmentów filmowych. Lee wzbogaca narrację o wykorzystanie innych narzędzi poza przeglądarką i serwisem gromadzącym materiały wideo. Kluczowa wydaje się tu inspiracja interfejsem programu Prezi służącego do przygotowywania wyświetlanych na wirtualnym płótnie $2.5 \mathrm{D}$ prezentacji multimedialnych, których elementy pokazywane są za pomocą techniki przybliżania kolejnych slajdów, a następnie oddalania, obejmującego całą planszę. W Prema$k e^{\prime} u$ tym wirtualnym płótnem jest mapa lokacji, gdzie realizowano zdjęcia do Wieku zagłady, zaś w obrębie slajdów Lee umieszcza informacje o mieście i liczbę powstałych tam materiałów audiowizualnych. Pomocne okazało się również Google Maps, z którego autor korzysta, by zaznaczyć, w jakiej części miasta powstał dany film, a tym samym bardziej szczegółowo scharakteryzować przebieg produkcji Wieku zagtady. Warto odnotować, że im dalej od centrum amerykańskich miast, tym mniej materiałów making-of nakręconych przez użytkowników YouTube'a - co więcej, pokazanie się z kamerą w miejscach z założenia niedostępnych dla publiczności alarmowało przedstawicieli studia produkcyjnego, którzy wypraszali osoby dysponujące sprzętem do rejestracji z terenu wynajętego na potrzeby kręcenia filmu. Przynajmniej to można wywnioskować z wideoeseju, ale wydaje się, że niekoniecznie musi się to mijać z prawdą.

Działanie według ściśle określonych reguł i zgodnie z ustalonym wcześniej scenariuszem zostaje zresztą żartobliwie podsumowane w Premake'u. W jednej $\mathrm{z}$ ostatnich scen dzieła Lee zacytowano relację z konwencji firmy Samsung (reklamującej akurat nowe telewizory), na którą został zaproszony Michael Bay. Stojący przed publicznością reżyser w pewnym momencie przestał mówić, gdyż, jak sam głośno zaznacza, wadliwy teleprompter nie wyświetlał mu tekstu do odczytania. Zaskoczony, nieprzygotowany do spontanicznej wypowiedzi na miej- 
scu, wreszcie - skompromitowany Bay po chwili przeprasza i schodzi ze sceny, nie odpowiadając na pytanie o inspiracje i swój sposób pracy, stając się następnie bohaterem nagłówków informujących o wpadce popularnego realizatora. Wpadce zapewne nieprzewidzianej w starannie zaplanowanej kampanii reklamowej czwartej części Transformers. I choć ta „usterka” nie wpłynęła w znaczący sposób na wyniki frekwencyjne Wieku zagtady, to wspomniane wyżej zdarzenie nie zostało pominięte przez twórcę Premake’u, ironicznie odnoszącego się do charakteryzowanego zjawiska postprodukcji i reklamy współczesnego blockbustera.

Wideoesej Lee, mimo struktury opierającej się przede wszystkim na nagromadzeniu cytatów i braku narracji prowadzonej z offu ${ }^{12}$, charakterystycznej dla dotychczasowych krytyczno-audiowizualnych dzieł Amerykanina, jest tekstem w pełni autorskim w tym sensie, że poprzez dobór materiałów i charakterystycznego sposobu opowiadania twórca zaznacza swoją perspektywę i wyraża ambicję wypunktowania istotnego zjawiska. Przenośne znaczenie niektórych scen zdaje się tę perspektywę potwierdzać. W jednym z zacytowanych nagrań słyszymy mężczyznę oglądającego uliczne plakaty powstałe na potrzeby kampanii reklamowej Wieku zagtady ${ }^{13}$ - widać na nich grafiki z Deceptikonami (czyli przeciwnikami Autobotów, pozytywnych bohaterów serii Transformers) i hasłami w rodzaju: „He's watching you” [on cię obserwuje], „It's watching you” [to cię obserwuje], czy „Report alien activity” [zgłaszaj aktywność obcych], co - biorąc pod uwagę koncentrację Lee na aspekcie produkcji filmu - koresponduje z metodami stosowanymi przez studio Paramount, bacznie przyglądające się aktywności użytkowników i fanów.

Nie mniej ironiczne są nawiązania do ulubionego wizualno-dźwiękowego motywu Baya, czyli scen wybuchów, których oglądania i słuchania widz z pewnością doświadczy w trakcie projekcji jakiegokolwiek filmu reżysera Pearl Harbor $(2001)^{14}$. Lee nawiązuje do eksplozji kilkukrotnie - albo prezentując w ob-

12 Początkowo Lee pracował nad wersją Premake’u, w której voice over był używany, jednakże, jak sam zaznaczał, ten sposób budowania narracji tym razem kompletnie się nie sprawdził (Lee, 2020).

${ }^{13} \mathrm{Na}$ marginesie można dodać, że kampania reklamowa Wieku zagtady wyraźnie odnosiła się do fabuły trzeciej odsłony cyklu, Transformers 3 (2011, reż. M. Bay), gdzie roboty zostały oskarżone o działanie na szkodę ludzkości. Na początku 2014 roku na ulicach miast (zwłaszcza w Chicago) pojawiały się więc plakaty informujące o dalszym zagrożeniu ze strony transformerów. Powstała także strona internetowa www.transformersaredangerous.com, na której znalazło się więcej informacji o rzekomym niebezpieczeństwie (dziś po wpisaniu powyższego adresu zostajemy przekierowani na facebookowy profil serii Transformers), zaś dzwoniąc pod numer telefonu znajdujący się na billboardzie z teasera promującego Wiek zagtady, można było usłyszeć komunikat ostrzegający przed kontaktem z robotami (Eisenberg, 2014).

${ }^{14}$ Do wybuchów w filmach reżyserowanych przez Michaela Baya nawiązuje sporo memów (wystarczy zerknąć do wyszukiwarki po wpisaniu nazwiska twórcy i hasła „explosions”). Charakterystyczny komponent wizualno-akustyczny opisuje Tony Zhou w swoim wideoeseju What Is Bayhem? (Zhou, 2014). 
rębie jednego ekranu fragmenty kilku amatorskich filmów naraz, gdzie akurat filmowano scenę, w której miałoby dojść do eksplozji, albo też multiplikując włączające się pliki wideo (widać na nich czarny ekran z charakterystycznym podpisem: „Opening...” i ikoną ładowania) i dodając stosowną oprawę audialną, sugerującą jakiegoś rodzaju „eksplozję” związaną z nadmiarem otwartego oprogramowania. Ów nadmiar zdaje się szczególnie fascynować wideoeseistę, który sam z liczbą materiałów dotyczących powstawania filmu mierzył się przez kilka miesięcy. Swoboda w ich doborze na potrzeby montażu autorskiego audiowizualnego tekstu niejako koresponduje z ideą eseju jako takiego - Lee tworzy Prema$k e$ jako utwór uwypuklający sieć dyskursów i unaoczniający działanie machiny produkcyjnej, której aktywnym uczestnikiem stał się także widz. Perspektywa odbiorcy może być jednak - co także podkreśla opisywany wideoesej - różna, w zależności od miejsca zamieszkania (vide dysproporcje w liczbach amatorskich nagrań dotyczących realizacji Wieku zagtady). To z kolei prowadzi do jeszcze jednej kwestii opisywanej przez Lee: koprodukcji filmu z podmiotami z Chin.

\section{Wobec Chinawood}

Kevin Lee wspominał, że procesem powstawania czwartej części Transformers zainteresował się dopiero po obejrzeniu krótkiego filmu internetowego, w którym można zobaczyć kręcenie sceny eksplozji na ulicy chińskiego miasta. Tę scenę zarejestrowano jednak nie w Państwie Środka, ale w Detroit (Lee, 2020). I choć fakt „odgrywania” jednego miasta przez inne również zostaje ironicznie przywołany w Premake’u, to nie sposób pominąć faktu, że film Baya jest jednym $\mathrm{z}$ ważniejszych dzieł ostatniego dziesięciolecia pod względem pogłębienia relacji amerykańsko-chińskich poprzez koprodukcję filmów.

Rozwinięcie wątku Chin w wideoeseju Lee jest wynikiem internetowego śledztwa. Autor, wyliczając kolejne nagrania i informując o miejscu ich realizacji, wskazuje również na Hongkong i Narodowy Park Geologiczny Wulong Karst. Warto zauważyć, że w drugim z wymienionych miejsc powstały wyłącznie krótkie reportaże telewizyjne, a Lee nie odnalazł w internecie ani jednego amatorskiego filmu nakręconego w Chinach kontynentalnych, co dowodzi odmiennych strategii marketingowych prowadzonych przez producentów z China Movie Channel i Jiaflix Enterprises LCC. Pośród zacytowanych materiałów można zobaczyć wywiady z Bayem lub relacje z imprez zorganizowanych w celu zacieśnienia relacji między USA a Państwem Środka (w jednej z nich widać aktorkę Li Bingbing wyznającą na scenie miłość reżyserowi). Organizacja zdjęć w parku Wulong Karst, jak się dowiadujemy, nie była na rękę okolicznym handlowcom, którzy na czas produkcji musieli zamknąć sklepy, jednak, jak sami 
zaznaczają - zapewne również z ostrożności i lęku przed władzami - gotowy film miał wypromować region, co w przyszłości mogłoby być opłacalne również i dla nich jako sprzedawców.

Na ekranie swojego komputera Lee prezentuje sieć materiałów dotyczących zależności amerykańsko-chińskich w kontekście realizacji Wieku zagłady. Zacytowany zostaje fragment krótkiego filmu, w którym jeden z fanów serii sugeruje, że wygląd kompletnie różniącego się od swej wersji z serialu animowanego Grimlocka nawiązuje do powszechnych wyobrażeń smoka chińskiego, jednego z popularniejszych stworów z tamtejszej mitologii. W podobnym tonie został napisany krótki tekst - również przywołany w Premake’u - którego autor zastanawia się, czy wspomniany robot będzie przemawiać w języku mandaryńskim, co mogłoby wynikać z umowy między producentami filmu (Nguyen, 2014) ${ }^{15}$. Z kolei kilka oficjalnych reportaży prezentuje amerykańskich twórców czwartej części Transformers dowodzących, że „kino jako forma sztuki jest zdolne do przekraczania granic i zbliżania oddalonych od siebie kultur”, czego dowodem miałby być powstający Wiek zagtady.

Z powyższym kontrastuje decyzja producentów, by znaczną część zdjęć zrealizować w Detroit, w którym akurat nie rozgrywa się akcja filmu. Miasto ze stanu Michigan - jak zostało powiedziane - tak naprawdę udaje Hongkong, a powodem, dla którego zdecydowano się zorganizować w nim zdjęcia, były ulgi podatkowe, jakie przyznano studiu Paramount na potrzeby produkcji. Dlatego też, kiedy widzimy Michaela Baya mówiącego w wywiadzie dla chińskiej telewizji, że to był jego „pomysł, by tutaj [tj. w parku Wulong Karst - przyp. P.B.] kręcić film” i „nie chodzi tu o box office”, możemy się domyślać - a przynajmniej Lee taką interpretację wyraźnie sugeruje - że, wbrew słowom reżysera, finanse odgrywają kluczową rolę w podejmowanych przez producentów krokach.

Fakt, że Wiek zagtady swoją światową premierę miał w Hongkongu, nie jest bez znaczenia - choć wideoesej Lee o tym, ze względu na wcześniejszą publikację w internecie, nie informuje. Rynek filmowy w Chinach od pewnego już czasu rozrastał się w imponującym tempie ${ }^{16}$ - stąd termin „Chinawood” na określenie tworu mającego ambicję być zarówno konkurencją dla amerykańskich blockbusterów, jak i stanowić sieć przemysłu nastawionego na promocję wartości narodowych

15 Na marginesie warto dodać, że w opisywanym filmie Grimlock się po prostu nie odzywa, a dosiadający go Optimus Prime, przywódca Autobotów, wydaje mu rozkazy i stawia ultimatum, wedle którego Dinoboty muszą pomóc w ratowaniu Ziemi, bo w innym wypadku mogą zostać zniszczone przez pozostałe maszyny. Trudno powyższego nie interpretować w kontekście próby ustalenia symbolicznej podrzędno-nadrzędnej relacji, w której podmiot amerykański dominuje nad producentem z Chin.

16 Pisze o tym więcej Marcin Adamczak w swojej książce o światowych przemysłach filmowych (Adamczak, 2019, s. 141-217). 
(Davis, 2010, s. 124) - więc chęć nawiązania współpracy ze strony amerykańskiej wydawała się logiczną konsekwencją komercyjnych sukcesów w Państwie Środ$\mathrm{ka}^{17}$. Aynne Kokas swoją książkę poświęconą amerykańsko-chińskiej kooperacji filmowej zaczyna od uwagi dotyczącej Wieku zagtady jako dzieła znamiennego dla relacji między hegemonem współczesnej produkcji filmowej z USA a chętnie z nim współpracującymi chińskimi firmami, hojnie zresztą finansującymi powstawanie amerykańskich blockbusterów (Kokas, 2017, s. 1). Proces produkcji czwartej części Transformers - zwłaszcza jego ukazanie w Premakéu - potwierdza więc chęć rozwijania sieci kontaktów Hollywood w Chinach w celu „ekspansji pionowo i poziomo zintegrowanych konglomeratów medialnych" (Kokas, 2017, s. 27), co z czasem prowadziło do powstania kolejnych filmów mogących potencjalnie podbić światowy box office: Kung Fu Pandy 3 (2016, reż. J. Yuh-Nelson, A. Carloni), Bumblebee (2018, reż. T. Knight) czy aktorskiego remake’u Mulan (2020, reż. N. Caro). Wiek zagtady wydaje się być pod pewnymi względami osobliwą reklamą (uwypukla to również kilka zacytowanych w wideoeseju krótkich telewizyjnych reportaży) służącą dowiedzeniu, że współpraca z Chinami jest dla producentów z Hollywood po prostu opłacalna. Niezależnie od tego, czy szczerze myślą oni o misji „zbliżania oddalonych od siebie kultur".

\section{Wideoeseistyczna metarefleksja}

Wideoesej Lee, przez niektórych ironicznie uznawany za najlepszą część serii o popularnych robotach (Franich, 2014), co prawda pomyślany przede wszystkim jako audiowizualny tekst relacjonujący niuanse produkcji hollywoodzkiego blockubustera, jest utworem faktycznie odnoszącym się do wielu różnorodnych kwestii. Premake jest więc dokumentem o zmieniającej się roli współczesnego widza (tyleż odbiorcy, co również twórcy); szkicem o postępujących możliwościach manipulowania przekazem ze względu na powszechny dostęp do specjalistycznego oprogramowania; pełnym cytatów remiksem różnego rodzaju nagrań zacytowanych w celu prezentacji wielu, niekiedy odmiennych punktów widzenia; esejem o internecie i ewoluującej kulturze konwergencji, której charakter jest coraz bardziej nieuchwytny ze względu na bogactwo otaczających tekst główny „współegzystujących” z nim elementów (w tym paratekstów w rodzaju Prema$\left.k e^{\prime} a\right)$; niefikcjonalnym metafilmem o wideoeseju jako takim - jego ograniczeniach i możliwościach; wreszcie też, co wiąże się z poprzednią cechą, dziełem o metodzie badań production i audience studies. To z jednej strony tekst anali-

\footnotetext{
${ }^{17}$ Kolejne lata potwierdzały dominującą rolę chińskiej kinematografii w światowym box offiice, dlatego nikogo już nie dziwiły propozycje współpracy wychodzące ze strony amerykańskich producentów. Zob. więcej na ten temat: Demiańczuk, 2020, s. 40-42; odcinek podkastu prowadzonego przez Marcina Krasnowolskiego i Jagodę Murczyńską, https://azjakreci.podbean.com/e/azja-kreci-odcinek13-mulan-czyli-chiny-w-hollywood/ (dostęp: 29.09.2020).
} 
tyczny, poddający krytycznej refleksji szereg zjawisk, z drugiej zaś utwór, który można analizować nie tylko jako wideopublikację (popularno)naukową ( $\mathrm{z}$ wyraźnymi „przypisami” - ich rolę pełnią tu wszechobecne adresy internetowe, które pozwalają ustalić tok poszukiwań autora), ale też krótkometrażowy film skoncentrowany na kinie.

Z pewnością Premake prowokuje do rozwinięcia przyjmowanej dotychczas niekiedy perspektywy, zgodnie z którą moglibyśmy definiować wideoesej jako „wypowiedź audiowizualną o charakterze interpretacyjnym w odniesieniu do filmu lub grupy filmów" (Koschany, 2018, s. 31) - interpretacja Wieku zagtady, z oczywistych względów, nie jest w tym wypadku możliwa, a jednak przez całą projekcję pamiętamy, do jakiego filmu Lee nawiązuje. Decyzja amerykańskiego wideoeseisty o opublikowaniu swojego utworu przed premierą hollywoodzko-chińskiego blockbustera wydaje się zresztą znamienna - oto swego rodzaju (audiowizualny) komentarz dotyczący dzieła Paramount Pictures pojawia się jeszcze przed jego pierwszymi oficjalnymi projekcjami. Co więcej - jest to tylko jeden z komentarzy, w dodatku nawiązujący do innych opinii i opierający swoją kompozycję na ich istnieniu.

Usytuowanie w centrum pozaestetycznych aspektów Wieku zagtady jest, jak się wydaje, sprzężone z przemianami w zakresie kultury audiowizualnej. Film Michaela Baya, jak najpewniej sugerowałby wideoeseista, nie ma bowiem większego znaczenia (pod względem fabularnym czy estetycznym). Lee w Premake'u nade wszystko interesuje rozpoznanie fenomenu związanego z relacją ukształtowaną na linii studio: odbiorca. Dlatego w pierwszej kolejności twórca przedstawia kulisy (obserwowane, co istotne, z perspektywy osoby niezaangażowanej w samą produkcję filmu) strategii marketingowej współczesnego blockbustera w dobie partycypacji oraz zastanawia się nad sposobami wykorzystywania przez studio materiałów zrealizowanych przez amatorów. Istotnie gdyby nie działalność serwisów typu YouTube czy Vimeo, reklamowanie Wieku zagtady przebiegałoby inaczej i najpewniej nie angażowałoby w taki sam sposób ulicznych przechodniów.

W kontekście powyższych konstatacji nie bez znaczenia pozostają ostatnie momenty wideoeseju Lee, w których na ekranie laptopa widzimy wśród otwartych okien jedno z filmem przedstawiającym odbijających się w szybie ludzi, którzy trzymają aparaty i telefony. „Powinniśmy to zarejestrować” - słychać z offu kobietę. Jej wypowiedź uwypukla powszechną potrzebę ludzi do uwieczniania najrozmaitszych zjawisk, wydarzeń czy osób na swoich elektronicznych urządzeniach. Ponadto przywołane wyżej ujęcie nawiązuje do zastosowanej w Premake'u polifonicznej narracji. Wideoesej Lee, cytujący setki rozmaitych nagrań, oglądany pod tym kątem staje się, jak zaznaczono, utworem o nadmiarze. Łatwo sobie wyobrazić 
dłuższą wersję opisywanego dzieła, bo baza zamieszczonych w sieci quasi-dokumentów z każdym miesiącem się rozrasta. Kwestia nadmiaru dotyczy jednak nie tylko liczby samych filmów w internecie, ale też tropów, jakimi można podążyć po zapoznaniu się z tymi filmami (vide wspomniane wyżej możliwości odczytań wideoeseju Lee). Premake jest więc także utworem akcentującym nieustannie multiplikowane i rozwarstwiające się narracje związane $\mathrm{z}$ analizowanym zagadnieniem. Finałowa kanonada wyskakujących okienek - mających zademonstrować, jak wiele udało się znaleźć materiałów dotyczących produkcji Wieku zagtady - niejako potwierdza bezradność narratora/odbiorcy, który w obliczu tak wielu ścieżek interpretacyjnych decyduje się poddać refleksji kilka tematów jednocześnie.

Opisywany desktop documentary wpisuje się także w zagadnienie współczesnej odmiany kinofilii - stale ewoluującej pod wpływem nowych mediów. Już w roku pojawienia się YouTube’a Thomas Elsaesser zastanawiał się nad istnieniem kinofilii „postartystycznej” i „postteoretycznej”, która przyswaja nowe technologie i krzewi się w internecie (Elsaesser, 2012, s. 19). Pisząc o ściąganiu plików, wymienianiu się nimi, samplowaniu i przemontowywaniu, teoretyk zarówno wskazywał na możliwości tekstowych manipulacji, jakie dane są użytkownikowi, jak też akcentował charakter fragmentaryczny i fetyszystyczny pracy utrwalania oraz odtwarzania (tamże, s. 23). Powstały niespełna dziesięć lat później wideoesej Lee zdaje się w pisywać w kolejną epokę kinofilii, w której film - w tym wypadku czwarta część cyklu Transformers - jeszcze bardziej traci na znaczeniu, zyskuje zaś to, co jest z nim pośrednio związane. W centrum usytuowany zostaje zaś odbiorca: widz, który przygląda się innym widzom; i widz-twórca analizujący własną metodę pracy poprzez ukazanie na ekranie różnorodności tekstowych manipulacji.

Premake, jako desktop documentary, jest prawdziwie współczesnym metafilmem, którego proces (post)produkcji przebiega „performatywnie”, na naszych oczach (Bešlagić, 2019, s. 57). Nie bez znaczenia są tu więc wszelkie zbliżenia na otwierające się okna, ekrany ładowania, eksplorowanie plików, sceny ujawniania manipulacji posiadanym materiałem audiowizualnym, czy uwypuklanie dostępu do niemal nieskończonej liczby źródeł. Patrząc zaś szerzej, można uznać, że refleksyjna płaszczyzna Premake’u na swój sposób podkreśla także rosnące znaczenie wideoeseju jako formy wypowiedzi - formy, której poświęcone są serwisy internetowe (choćby prowadzone przez Catherine Grant Audiovisualcy. An Online Forum for Videographic Film Studies ${ }^{18}$ ), periodyki naukowe (vide „[In]Transition. Journal of

\footnotetext{
18 Zob. https://vimeo.com/groups/audiovisualcy (dostęp: 20.08.2020).
} 
Videographic Film \& Moving Image Studies"19), artykuły naukowe ${ }^{20}$, wreszcie też zestawienia najlepszych wideoesejów danego roku (patrz: rankingi publikowane na stronie internetowej brytyjskiego magazynu „Sight \& Sound”21).

Transformers: The Premake wskazuje na nowy obszar „badan” wideoeseistyki i kina w ogóle, w ramach którego refleksywne desktop documentaries mogłyby łączyć krytyczny namysł nad danym problemem z analizą użytych przez siebie środków. Biorąc pod uwagę, że po filmie skoncentrowanym na realizacji Wieku zagtady nie tylko Kevin B. Lee montował utwory utrzymane w tej poetyce ${ }^{22}$, można domniemywać, że wkrótce powstanie więcej tego rodzaju wideoesejów. Czas pokaże, na ile Premake okaże się dziełem przełomowym - zarówno dla amerykańskiego twórcy, jak i dla wideoeseistyki w ogóle.

\section{Bibliografia:}

Adamczak, M. (2019). Kapitaty przemystu filmowego. Hollywood, Europa, Chiny. Warszawa: Wydawnictwo Naukowe PWN.

Adamczak, M. (2015). Obok ekranu. Perspektywa badań produkcyjnych a spoteczne istnienie filmu. Poznań: Wydawnictwo Naukowe UAM.

Avissar, A., DiGravio, W., Lee, G. (2020). The Best Video Essays of 2019, https://www2. bfi.org.uk/news-opinion/sight-sound-magazine/polls-surveys/best-video-essays-2019 (dostęp: 20.08.2020).

Bešlagić, L. (2019). Computer Interface as Film: Post-Media Aesthetics of Desktop Documentary, Am Journal, No. 20.

Biliński, P. (2016). Palimpsesty. Wideoeseistyka Kevina B. Lee, Ekrany, nr 5.

Boone, S. (2014). Kevin B. Lee's Transformers: The Premake,

https://www.rogerebert.com/features/kevin-b-lees-transformers-the-premake (dostęp: 28.09.2020).

19 Periodyk, rzecz jasna, publikowany jest wyłącznie online, a autorzy wideoesejów oprócz swoich audiowizualnych prac zamieszczają na jego łamach również teksty przybliżające cele czy inspiracje oraz opisują swoje metody twórcze. Zob. http://mediacommons.org/intransition/ (dostęp: 20.08.2020).

${ }^{20}$ Pośród polskich prac traktujących o interesującym nas zagadnieniu na szczególną uwagę zasługują zwłaszcza dwa szkice (zob. Liguziński, 2012; Świętochowska, 2018).

${ }^{21}$ Do przygotowania zestawienia zapraszani są najważniejsi wideoeseiści świata - wśród nich jest także bohater niniejszego artykułu. Zob. https://www2.bfi.org.uk/news-opinion/sight-sound-magazine/ polls-surveys/best-video-essays-2019 (dostęp: 20.08.2020).

22 Vide choćby zrealizowane przez Lee i Chloé Galibert-Laîné Reading // Binging // Benning (2018, https://vimeo.com/252840859, dostęp 30.09.2020) czy Watching The Pain of Others (2018, https:// vimeo.com/298425068, dostęp 30.09.2020) Galibert-Laîné - wideoeseje, których (współ)autorka zastanowiała się nad procesem oglądania filmów i wpływu projekcji konkretnych utworów na samego odbiorcę. W obu dziełach widać pulpit komputera i nie bez znaczenia pozostaje to, co narratorzy decydują się umieścić w obrębie ekranu, niejednokrotnie wykorzystując możliwość otwarcia wielu okien jednocześnie i ukazania ich odbiorcy wideoesejów. 
Burgess, J., Green, J. (2014). Przedsiębiorczy vloger: kultura uczestnictwa poza podziałem na profesjonalistów i amatorów (tłum. D. Rode). W: Badanie widowni filmowej. Antologia przektadów, K. Klejsa, M. Saryusz-Wolska (red.). Warszawa: Wydawnictwo Naukowe Scholar.

Davis, D.W. (2010). Market and Marketization in the China Film Business, Cinema Journal, Vol. 49, No. 3.

Demiańczuk, J. (2020). Chinawood, Polityka, nr 38.

Eisenberg, E. (2014). Transformers: Age of Extinction Viral Found In New Trailer, https://www.cinemablend.com/news/Transformers-Age-Extinction-Viral-Found-Trailer-41961.html (dostęp: 20.09.2020).

Elsaesser, T. (2012). Kinofilia albo pożytki z odczarowania (tłum. M. Szczubiałka), Panoptikum, nr 11 .

Franich, D. (2014). Transformers: The Premake Is the Best Transformers Movie Ever, Entertainment Weekly, https:/ew.com/article/2014/06/19/transformers-premake/ (dostęp: 29.09.2020).

Galibert-Laîné, Ch. (2018). Watching the Pain of Others, https://vimeo.com/298425068 (dostęp 30.09.2020).

Galibert-Laîné, Ch., Lee, K. B. (2018). Reading // Binging // Benning, https://vimeo. com/252840859 (dostęp 30.09.2020).

Kokas, A. (2017). Hollywood Made in China. Oakland: University of California Press.

Koschany, R. (2018). Fenomenologia obrazów filmowych. Wideoesej jako krytyka tematyczna i sztuka interpretacji, Kwartalnik Filmowy, nr 104.

Kożuchowski, T. (2019). Making-of. (Nie)zwykły dodatek, Ekrany, nr 3-4.

Krasnowolski, M., Murczyńska, J. (2020). Mulan, czyli Chiny w Hollywood, [odcinekpodcastu Azja kręci. Podcast filmowy], https://azjakreci.podbean.com/e/azja-kreci-odcinek-13-mulan-czyli-chiny-w-hollywood/ (dostęp: 29.09.2020).

Kurz, I. (2010). „I got you tube”. Kino a serwis YouTube.com - odmiany kinofilii.

W: Pogranicza audiowizualności. Parateksty kina, telewizji i nowych mediów, A. Gwóźdź (red.). Kraków: Universitas.

Lee, K.B.(2015). Breaking through the Screen. The Video Essays of Mark Rappaport, https:// vimeo.com/196762561 (dostęp: 20.08.2020).

Lee, K.B. (2020). Learning Farocki, https:/www.alsolikelife.com/learning-farocki (dostęp: 20.08.2020).

Lee, K.B. (2020). The Making of Transformers the Premake, https://vimeo. com/415018869 (dostęp: 20.08.2020).

Lee, K.B. (2009). The Viewer as Creator. On Shooting Down Pictures Video Essays, https://www.kunst-der-vermittlung.de/dossiers/internet-weblogs/kevin-lee-on-shooting -down-pictures/ (dostęp: 20.08.2020).

Liebman, M. (2014). Transformers: Age of Extinction Blu-ray Review. These Transformers Haven't Changed, https://www.blu-ray.com/movies/Transformers-Age-of-Extinction -Blu-ray/83888/\#Review (dostęp: 20.08.2020). 
Liguziński, S. (2012). Wideoesej. Zapiski na marginesach, Ekrany, nr 6.

Lopate, P. (2020). Mark Rappaport's Essay Films, Cineaste, Vol. 45, No. 2.

Nguyen, J. (2014). Will Grimlock speak Mandarin in Transformers: Age of Extinction?, http://nerdreactor.com/2014/02/02/will-grimlock-speak-mandarin-in-transformers-age -of-extinction/ (dostęp: 30.09.2020).

Skinner, C. (2014). Transformers: The Premake Takes an Amusing Look at „Crowdsourced Movie Promotion”, https://www.craigskinnerfilm.com/transformers-the-premake-takes -an-amusing-look-at-crowdsourced-movie-promotion/ (dostęp: 20.08.2020).

Steffen, D. (2015). Exploring Virtual Space: Talking Transformers: The Premake with Kevin B. Lee, https://truefalse.org/exploring-virtual-space-talking-transformers-the-premake-with-kevin-b-lee/ (dostęp: 20.08.2020).

Świętochowska, G. (2018). Wideoesej, czyli od Chrisa Markera do Fandoru. Historia awansu pewnej formy audiowizualnej wyrosłej z kinofilii, Kwartalnik Filmowy, nr 104.

Zając, B. (2010). Między słowem a obrazem. Dyskurs eseju filmowego, Kwartalnik Filmowy, nr 71-72.

Zhou, T. (2014). What Is Bayhem?, https://vimeo.com/99798626 (dostęp: 24.09.2020).

\section{Summary:}

\section{Desktop documentary. On the making, narrative and contexts of Kevin B. Lee's Transformers: The Premake}

The paper focuses on an analysis of Kevin B. Lee's video essay Transformers: The Premake. The Author refers to the narrative components of the film and to the context of its production (which is also one of the themes of the analyzed video essay). Transformers: The Premake is characterized not only by the work of Lee - one of the most appreciated contemporary video essayists - but also as a film on production and audience studies. As a desktop documentary, Lee's video essay is a self-reflexive film in which the main topic - in this case the more or less conscious participation of spectators in the process of the promotion of $\mathrm{Mi}$ chael Bay's Transformers: Age of Extinction - remains as important as the editing of The Premake: video essay on the work of contemporary film/video essayist, who shapes the narration of his film with the usage of material available on the Internet (videos on YouTube or Vimeo) and available software (Adobe Premiere, Google Maps, etc.).

Keywords: video essay, Lee, Transformers, documentary, desktop, YouTube 